\title{
Ramipril Affects Hydrogen Sulfide Generation in Mouse Liver and Kidney*
}

\author{
Bogdan WILIŃSKI, Jerzy WILIŃSKI, Eugeniusz SOMOGYI, Marta GÓRALSKA \\ and Joanna PIOTROWSKA
}

Accepted May 25, 2010

\begin{abstract}
WiLiŃSki B., WilińSki J., SOMOgYi E., GÓRAlSkA M., PiOtrowSKa J. 2010. Ramipril affects hydrogen sulfide generation in mouse liver and kidney. Folia biol. (Kraków) 58: 177-180.

Hydrogen sulfide $\left(\mathrm{H}_{2} \mathrm{~S}\right)$ is a modulator of various physiological and pathological processes in the cardiovascular and nervous system and plays an important role in the regulation of gastrointestinal tract, liver and kidney function. The effect of the pleiotropic action of the tissue specific angiotensin-converting enzyme inhibitor (ACEI), ramipril, exceeds renin-angiotensin aldosterone system (RAAS) blockade and involves different biological mechanisms. The aim of the study is to assess the influence of ramipril on $\mathrm{H}_{2} \mathrm{~S}$ production in mouse liver and kidneys. Thirty mice (CBA) of both sexes were given intraperitoneal injections of ramipril solutions $-0.125 \mathrm{mg}(5 \mathrm{mg} / \mathrm{kg}$ - group D1) and $0.25 \mathrm{mg}(10 \mathrm{mg} / \mathrm{kg}-$ group D2) for 5 consecutive days at the same time of the day $(10: 30 \mathrm{am})$. The control group received physiological saline in portions of the same volume $-0.2 \mathrm{ml}$. The measurements of the tissue concentration of $\mathrm{H}_{2} \mathrm{~S}$ were performed using the modified spectrophotometric method of Siegel. There was a significant rise in the tissue concentration of $\mathrm{H}_{2} \mathrm{~S}[\mu \mathrm{g} / \mathrm{g}]$ in livers of group D1 ( $2.70 \pm 0.02$ vs $2.81 \pm 0.06 ; \mathrm{P}=0.03)$ and group D2 ( $2.70 \pm 0.02$ vs $2.98 \pm$ $0.03 ; \mathrm{P}<0.001)$ and a significant decrease of $\mathrm{H}_{2} \mathrm{~S}$ kidney tissue concentration in group D1 $(3.35 \pm 0.06$ vs $3.15 \pm 0.07 ; \mathrm{P}=0.02)$ and in group $\mathrm{D} 2(3.35 \pm 0.06$ vs $2.89 \pm 0.03 ; \mathrm{P}<0.001)$. Our results show that ACEI ramipril affects hydrogen sulfide generation in mouse liver and kidneys.

Key words: Hydrogen sulfide, ramipril, angiotensin-converting enzyme inhibitor, renin-angiotensin aldosterone system, liver, kidney, mouse.

Bogdan WILIŃSKI, Marta GÓRALSKA, Department of Human Developmental Biology, Jagiellonian University Medical College, Kopernika 7, 31-034 Kraków, Poland.

E-mail: bowil@interia.pl

Jerzy WILIŃSKI, I Department of Cardiology and Hypertension, Jagiellonian University Medical College, Kopernika 17, 31-501 Kraków, Poland.

E-mail:putamen@interia.pl

Eugeniusz SOMOGYI, Joanna PIOTROWSKA, Department of Inorganic and Analytical Chemistry, Jagiellonian University Medical College, Medyczna 9, 30-688 Kraków, Poland.

E-mail: jpiotrowl@cm-uj.krakow.pl
\end{abstract}

Hydrogen sulfide $\left(\mathrm{H}_{2} \mathrm{~S}\right)$ is endogenously produced in enzymatic reactions in many tissues, especially in the nervous system, cardiovascular system, liver and kidney. $\mathrm{H}_{2} \mathrm{~S}$ acts as a gasotransmitter and serves as a modulator of various physiological and pathophysiological processes such as the regulation of vascular tone, myocardial contractility, neurotransmission, insulin secretion, biliary bicarbonate excretion, immune and inflammatory processes, gastric mucosal integrity, intestinal motility and perception (FIORUCCI et al. 2006; ŁOWICKA \& BEŁTOWSKI 2007). The reninangiotensin aldosterone system (RAAS) is a hor- monal cascade that functions in the homeostatic control of arterial pressure, tissue perfusion, extracellular volume, cell growth end proliferation, apoptosis, reactive oxygen species generation, inflammation and fibrogenesis. Deregulation of the RAAS plays an important role in the pathogenesis of cardiovascular and renal disorders and in the pathophysiology of liver diseases (LUBEL et al. 2008; WOLF 2008). The effects of ramipril - a member of the angiotensin-converting enzyme inhibitors (ACEIs) family - exceeds the RAAS blockade. The pleiotropic action of ACEIs is complex and involves numerous biological systems (ANDERSON 
et al. 2006; ASSELBERKS \& VAN GILST 2006). The impact of ACEIs on $\mathrm{H}_{2} \mathrm{~S}$ generation in liver and kidney is unknown. The aim of the study is to assess the influence of ramipril administration on endogenous $\mathrm{H}_{2} \mathrm{~S}$ concentration in mouse liver and kidney.

\section{Material and Methods}

Thirty CBA strain mice of both sexes (3.5-4 months old individuals) were used in the experiment.*. The study design comprised intraperitoneal injections of $0.125 \mathrm{mg}(5 \mathrm{mg} / \mathrm{kg}-$ group D1, $\mathrm{n}=10)$ and $0.25 \mathrm{mg}(10 \mathrm{mg} / \mathrm{kg}-$ group D2, $\mathrm{n}=10)$ for 5 consecutive days at the same time of the day (10:30 am). Ramipril - long acting tissue-specific non-sulfhydryl ACEI - was dissolved in physiological saline (each administration consisted of 0.2 $\mathrm{ml}$ of the solution). The control population $(\mathrm{n}=10)$ received intraperitoneally physiological saline of the same volume. The animals tolerated the applied doses of ramipril well and remained in good condition till the end of the experiment. Measure- portions were added, respectively. After 20 minutes in darkness the content was shaken for 1 minute with $1 \mathrm{ml}$ of chloroform. Absorbance was measured at $650 \mathrm{~nm}$ with the Varian Cary 100 spectrophotometer. A standard curve was obtained by iodometry of a solution of $0.0001 \mathrm{~mol} / \mathrm{l}$ sodium sulfide $\left(\mathrm{Na}_{2} \mathrm{~S}\right)$ in $0.01 \mathrm{~mol} / 1 \mathrm{NaOH}$. For each group of animals three concurrent analyses were performed and the average values of the results were calculated.

Statistical analysis was performed within the $\mathrm{R}$ Environment by the Student's $t$-test. Statistical significance was considered when $\mathrm{P}<0.05$.

\section{Results}

The administration of $0.125 \mathrm{mg}$ and $0.25 \mathrm{mg}$ ramipril (doses D1 and D2 respectively) caused a statistically significant increase in the liver $\mathrm{H}_{2} \mathrm{~S}$ tissue concentration by $4.1 \%$ and $10.4 \%$, respectively. Conversely, in the kidney ramipril led to the decrease of $\mathrm{H}_{2} \mathrm{~S}$ tissue concentration in the group D1 by $6.0 \%$ and in D2 by $13.8 \%$ (Table 1 ).

Table 1

Hydrogen sulfide tissue concentration in mouse liver and kidney following the administration of $0.125 \mathrm{mg}$ or $0.25 \mathrm{mg}$ of ramipril (groups D1 and D2 respectively)

\begin{tabular}{|l|c|c|c|c|c||}
\hline & $\begin{array}{c}\text { Control group } \\
(\mathrm{n}=10)\end{array}$ & $\begin{array}{c}\mathrm{D} 1 \\
(\mathrm{n}=10)\end{array}$ & $\begin{array}{c}\mathrm{P} \\
(\text { control vs D1) }\end{array}$ & $\begin{array}{c}\mathrm{D} 2 \\
(\mathrm{n}=10)\end{array}$ & $\begin{array}{c}\text { P } \\
\text { (control vs D2) }\end{array}$ \\
\hline $\begin{array}{l}\text { Liver } \mathrm{H}_{2} \mathrm{~S} \text { tissue concentration } \\
{[\mu \mathrm{g} / \mathrm{g}]}\end{array}$ & $2.70 \pm 0.02$ & $2.81 \pm 0.06$ & 0.03 & $2.98 \pm 0.03$ & $<0.001$ \\
\hline $\begin{array}{l}\text { Kidney } \mathrm{H}_{2} \mathrm{~S} \text { tissue concentration } \\
{[\mu \mathrm{g} / \mathrm{g}]}\end{array}$ & $3.35 \pm 0.06$ & $3.15 \pm 0.07$ & 0.02 & $2.89 \pm 0.03$ & $<0.001$ \\
\hline
\end{tabular}

ments of the $\mathrm{H}_{2} \mathrm{~S}$ concentration were performed by the use of the modified method of SIEGEL (1965).

Two hours after the last ramipril or physiological saline injection the animals were killed by cervical dislocation, their livers and kidneys were quickly removed and homogenized with $0.01 \mathrm{~mol} / 1$ sodium hydroxide $(\mathrm{NaOH})$ in proportion of 1 to 5 . Then $50 \%$ trichloroacetic acid (TCA) was added $(0.5 \mathrm{ml}$ to $2 \mathrm{~g}$ of liver samples in tight capsules of $3 \mathrm{ml}$ and $0.25 \mathrm{ml}$ to $1 \mathrm{~g}$ of kidney sample in tight capsules of $2 \mathrm{ml}$ ), the suspension was shaken and centrifuged. Subsequently, $1.5 \mathrm{ml}$ liver or $0.75 \mathrm{ml}$ kidney supernatant samples were moved to $2 \mathrm{ml}$ tight capsules with $0.15 \mathrm{ml}$ or $0.075 \mathrm{ml}$ of $0.02 \mathrm{~mol} / 1$ $\mathrm{N}, \mathrm{N}$-dimethyl-p-phenyl-diamine sulfate in $7.2 \mathrm{~mol} / \mathrm{l}$ hydrochloric acid $(\mathrm{HCl})$, then $0.15 \mathrm{ml}$ or $0.075 \mathrm{ml}$ of $0.03 \mathrm{~mol} / \mathrm{l}$ iron (III) chloride $\left(\mathrm{FeCl}_{3}\right)$ in $1.2 \mathrm{~mol} / 1 \mathrm{HCl}$

\section{Discussion}

Hydrogen sulfide biological action comprises several intracellular mechanisms and a complex interaction with carbon monoxide $(\mathrm{CO})$ and nitric oxide (NO) (ŁOWICKA \& BEŁTOWSKI 2007). Several digestive system diseases have been associated with perturbed $\mathrm{H}_{2} \mathrm{~S}$ production. Increased $\mathrm{H}_{2} \mathrm{~S}$ concentrations were observed in colitis, decreased values - in nonsteroidal anti-inflammatory drugs-induced (NSAID-induced) gastric mucosal injury and liver cirrhosis (DISTRUTTI et al. 2006; FIORUCCI et al. 2005a; FIORUCCI et al. 2005b). Combining data on the roles of RAAS and $\mathrm{H}_{2} \mathrm{~S}$ in the digestive system comes mainly from research on chronic liver disorders.

\footnotetext{
* The study has been performed in accordance with the guidelines for the care and use of laboratory animals accepted by Bioethical Committee of the Jagiellonian University Medical College.
} 
Hepatic fibrosis is considered a common response to many chronic hepatic injuries. Hepatic tissue remodelling is highly complex and involves several cell types, cytokines, chemokines, growth factors with hepatic stellate cells (HSC) and RAAS is thought to play an important role in this process. Angiotensin II (Ang II) promotes activation and differentiation of HSC into myofibroblasts and encourages myofibroblast contraction, proliferation and promotes the release of inflammatory cytokines as well as the deposition of extracellular matrix (ECM). Along with progressing fibrosis of the liver, portal hypertension develops, the main complication of cirrhotic liver. Fixed changes in hepatic structure account for approximately $70 \%$ of total resistance to portal blood flow in the cirrhotic liver. The remaining 30\% results from reversible resistance caused by the contraction of activated myofibroblasts positioned around the sinusoidial endothelial cells within the space of Disse architecture changes. Numerous systems and factors participate in the control of this resistance, such as RAAS, the autonomic nervous system, $\mathrm{NO}, \mathrm{H}_{2} \mathrm{~S}$, endotoxemia, oxidative stress, etc. (LUBEL et al. 2008). $\mathrm{H}_{2} \mathrm{~S}$ regulates perfusion pressure in normal and cirrhotic liver in a NO-independent manner; $\mathrm{NO}$ and $\mathrm{H}_{2} \mathrm{~S}$ are released by different cellular sources and their hemodynamic effects involve different cellular targets. $\mathrm{H}_{2} \mathrm{~S}$ generation in cirrhosis is decreased due to the reduced expression/activity of cystathione $\gamma$-lyase (CSE) in HSC - one of the main sources of $\mathrm{H}_{2} \mathrm{~S}$ in the liver (FIORUCCI et al. 2005).

Numerous studies using a variety of animal models of chronic liver diseases and results from a few human trials have demonstrated antifibrotic effects of RAAS blockade with ACEIs and angiotensin receptor blockers (ARBs). Significant reductions in serum markers of hepatic fibrosis such as transforming growth factor $\beta 1$ (TGF- $\beta 1$ ), type IV collagen, hyaluronic acid or procollagen III$\mathrm{N}$-peptide were observed and signs of lower necroinflammatory grade and less advanced stages of fibrosis in liver histology were observed in individuals treated with ACEI or ARB as compared to control groups (JONSSON et al. 2001; LUBEL et al.2008; RIMOLA et al. 2004; TERUI et al. 2002; TUNCER et al. 2003). RAAS blockade inhibits Ang II - TGF- $\beta 1$ axis and HSC activation one of the key pathologic hepatic fibrosis mechanisms (PEREIRA et al. 2009).

The role of $\mathrm{H}_{2} \mathrm{~S}$ in liver physiology and pathology and its interplay with RAAS definitely requires further investigation. Our study provides important information that the action of ACEI involves endogenous $\mathrm{H}_{2} \mathrm{~S}$ generation in liver. We may speculate that some of the biological effects of ACEIs can be mediated by $\mathrm{H}_{2} \mathrm{~S}$ and hydrogen sulfide might be an important element of the complex regulatory system of RAAS along with the recently discovered 'alternative arm of RAAS' formed by angiotensin converting enzyme 2, angiotensin 1-7 and mas receptor axis (ACE2 - Ang-(1-7) - mas receptor) (LUBEL et al. 2008).

In the kidney cystathione $\beta$-synthase (CBS) and $\mathrm{CSE}$ are required to produce $\mathrm{H}_{2} \mathrm{~S}$. Hydrogen sulfide has been recognized as a participant of the control of renal function which involves both vascular and tubular actions. In the study of XIA et al. (2009) induction of endogenous $\mathrm{H}_{2} \mathrm{~S}$ production with L-cysteine (L-Cys) infusion into renal artery increased glomerular filtration rate (GFR), urine blood flow, urinary sodium and potassium excretion, fractional excretion of sodium and potassium. The inhibitory effect of $\mathrm{H}_{2} \mathrm{~S}$ on tubular reabsorption has been shown to involve $\mathrm{Na}^{+} / \mathrm{K}^{+} / 2 \mathrm{Cl}^{-}$cotransporter (NKCC) and $\mathrm{Na}^{+} / \mathrm{K}^{+}$-ATPase (NKA). Exogenous $\mathrm{H}_{2} \mathrm{~S}$ produced dose-related increases in renal blood flow, GFR and urinary excretion.

Inhibition of RAAS with ACEIs and ARBs is a well established part of the treatment of chronic kidney disorders. These drugs, based on results from clinical trials including studies with ramipril such as The Heart Outcomes Prevention Evaluation (HOPE) and Ramipril Efficacy In Nephropathy (REIN), significantly slow the rate of decline in creatinine clearance and reduce or prevent an increase in albuminuria and proteinuria with the great clinical benefits of reduced dialysis and renal transplantation rates and a decline in all-cause and cardiovascular mortality (CHOJNOWSKA-JEZIERSKA \& KOZIRÓG 2005). Kidney RAAS action comprises interaction with the kinin system and is mediated by numerous biologically active agents such i.e. bradykinin, NO, prostaglandins, TGF- $\beta$, plasminogen activator inhibitor-1 (PAI-1) and aldosterone (TAAL \& BRENNER 2000). The kidney $\mathrm{H}_{2} \mathrm{~S}$ effect of GFR increases with a consequent rise in urinary volume. Urinary sodium excretion is opposite to Ang II which among many other cellular targets has a modulatory activating action on tubular NKA and NKCC. The role of $\mathrm{H}_{2} \mathrm{~S}$ in kidney function in normal conditions and in the development of chronic disorders, especially considering the broad array of $\mathrm{H}_{2} \mathrm{~S}$ biological mechanisms with its antifibrotic properties, is a field for future research. As our study has shown, ramipril decreased concentrations of $\mathrm{H}_{2} \mathrm{~S}$ in normal mice. The mechanisms of this effect are yet to be determined as well as the significance of $\mathrm{H}_{2} \mathrm{~S}$ concentration changes in physiology and pathology of the kidney caused by ACEIs with regards to the complexity of kidney para- and endocrine function control. Notably, even the effect of the RAAS blockade with ACEIs and ARBs on renal hemodynamics has been proven to be quite variable because of the counteracting influences of the associated decreases in systemic arterial pres- 
sure and impact of concomitant drugs, including diuretics or other specific conditions such as restricted sodium intake (KOBORI et al. 2007).

In its biological action ramipril affects $\mathrm{H}_{2} \mathrm{~S}$ tissue generation. $\mathrm{H}_{2} \mathrm{~S}$ is not only involved in physiological and pathophysiological processes, but might also partially account for the effects of drugs like aspirin, other NSAIDs and ACEIs (FIORUCCI et al. 2007; SREBRO et al. 2006; WILIŃSKI et al. 2008). This poses another argument for further research on the role of $\mathrm{H}_{2} \mathrm{~S}$ in different organs and systems and future studies on hydrosulfide (HS) donors and agents releasing $\mathrm{H}_{2} \mathrm{~S}$ in cardiovascular medicine, hepatology and nephrology.

\section{Acknowledgements}

This paper is dedicated to the memory of Professor Zbigniew SREBRO.

\section{References}

Anderson V. R., Perry C. M., Robinson D. M. 2006. Ramipril: a review of its use in preventing cardiovascular outcomes in high-risk patients. Am. J. Cardiovasc. Drugs 6: 417-432.

Asselberks F. W.,VAN GILst W. H. 2006. ACE inhibition and hypertension: pleiotropic effects. Medicographia 28 333-339.

CHOJNOWSKA-JEZIERSKA J., KozIRÓG M. 2005. Ramipril new insight. Contemporary drugs that are worth knowing. Wyd. Terapii. Monitor., Łódź 1-23. (In Polish).

Distrutti E., Sediari L., Mencarelli A., Renga B., ORlandi S., Russo G., CALiEndo G., SANTAGADA V. Cirino G., Wallace J. L., FioruCCI S. 2006. 5-Amino-2-hydroxybenzoic acid 4-(5-thioxo-5H-[1,2]dithiol-3yl)-phenyl ester (ATB-429), a hydrogen sulfide-releasing derivative of mesalamine, exerts antinociceptive effects in a model of postinflammatory hypersensitivity. J. Pharmacol. Exp. Ther. 319: 447-458.

Fiorucci S., Antonelli E., Distrutti E., Rizzo G., MENCARElli A., ORLANDi S., ZANARDO R., RENGA B., DI Sante M., Morelli A., Cirino G., Wallace J. L. 2005. Inhibition of hydrogen sulfide generation contributes to gastric injury caused by anti-inflammatory nonsteroidal drugs. Gastroenterology 129: 1210-1224.

Fiorucci S., Antonelli E., Mencarelli A., Orlandi S., RENGA B., RizzO G., Distrutti E., SHAH V., MORELli A. 2005. The third gas: $\mathrm{H} 2 \mathrm{~S}$ regulates perfusion pressure in both the isolated and perfused normal rat liver and in cirrhosis. Hepatology 42: 539-548.
Fiorucci S., Distrutti E., Cirino G., Wallace J. L. 2006. The emerging roles of hydrogen sulfide in the gastrointestinal tract and liver. Gastroenterology 131: 259-271.

Fiorucci S., SANTUCCI L., DistrutTi E. 2007. NSAIDs, coxibs, CINOD and H2S-releasing NSAIDs: what lies beyond the horizon. Dig. Liver Dis. 39: 1043-1051.

Jonsson J. R., Clouston A. D., Ando Y., Kelemen L. I., Horn M. J., AdAMSOn M. D., PuRdie D. M., POWEll E. E. 2001. Angiotensin-converting enzyme inhibition attenuates the progression of rat hepatic fibrosis. Gastroenterology 121: $148-155$.

Kobori H., Nangaku M., Navar L. G., Nishiyama A. 2007. The intrarenal renin-angiotensin system: from physiology to the pathobiology of hypertension and kidney disease. Pharmacol. Rev. 59: 251-287.

Lubel J. S., Herath C. B., Burrell L. M., Angus P. W. 2008. Liver disease and the renin-angiotensin system: recent discoveries and clinical implications. J. Gastroenterol. Hepatol. 23: 1327-1338.

ŁOWICKA E., BEŁTOWSKI J. 2007. Hydrogen sulfide (H2S) the third gas of interest for pharmacologists. Pharmacol. Rep. 59: 4-24.

Pereira R. M., dos Santos R. A., DA Costa Dias F. L., Teixeira M. M., Simoes E Silva A. C. 2009. Reninangiotensin system in the pathogenesis of liver fibrosis. World J. Gastroenterol. 15: 2579-2586.

Rimola A., Londono M. C., Guevara G., Bruguera M., NAVASA M., FORNS X., GARCIA-RETORTILlO M., GARCIA-VALDECASAS J. C., RODES J. 2004. Beneficial effect of angiotensin-blocking agents on graft fibrosis in hepatitis $\mathrm{C}$ recurrence after liver transplantation. Transplantation 78: 686-691.

SIEGEL L.M. 1965. A Direct Microdetermination for Sulfide. Anal. Biochem. 11: 126-132.

Srebro Z., Somogyi E., Wiliński B., GóralsKa M., WILIŃSKI J., SURA P. 2006. Aspirin augments the concentration of endogenous hydrogen sulfide in mouse brain and liver. Folia Med. Cracov. 47: 87-91.

TAAL M. W., BRENNER B. M. 2000. Renoprotective benefits of RAS inhibition: from ACEI to angiotensin II antagonists. Kidney Int. 57: 1803-1817.

Terui Y., Saito T., Watanabe H., Togashi H., KaWata S., KamAdA Y., SAKUTA S. 2002. Effect of angiotensin receptor antagonist on liver fibrosis in early stages of chronic hepatitis C. Hepatology 36: 1022-1029.

Tuncer I., OzBEK H., UGras S., BAYraM I. 2003. Antifibrogenic effects of captopril and candesartan cilexetil on the hepatic fibrosis development in rat. The effect of AT1-R blocker on the hepatic fibrosis. Exp. Toxicol. Pathol. 55: 159-166.

Wiliński J., SOMOGYI E., GóRAlsKa M., WilińsKi B., CZARNECKA D. 2008. Ramipril enhances the endogenous hydrogen sulfide tissue concentration in mouse heart and brain. Folia Med. Cracov. 3-4: 123-130.

WolF G. 2008. Novel aspects of the renin-angiotensinaldosterone-system. Front. Biosci. 13: 4993-5005.

Xia M., Chen L., MuH R. W., Li P. L., Li N. 2009. Production and actions of hydrogen sulfide, a novel gaseous bioactive substance, in the kidneys. J. Pharmacol. Exp. Ther. 329: 1056-1062. 